\title{
The performance and importance of the dental surgeon in an Intensive Care Unit
}

\author{
A atuação e importância do cirurgião-dentista em uma Unidade de Terapia Intensiva \\ La actuación e importancia del cirujano dental en una Unidad de Cuidados Intensivos
}

Received: 11/07/2021 | Reviewed: 11/13/2021 | Accept: 11/22/2021| Published: 12/04/2021

Lasthenia Drumond Santos

ORCID: https://orcid.org/0000-0001-9534-9480 Centro Universitário de Belo Horizonte, Brazil E-mail: lastheniadru@gmail.com

Julia Carneiro dos Santos

ORCID: https://orcid.org/0000-0003-2802-5640 Centro Universitário de Belo Horizonte, Brazil E-mail: julinha_carneiro@hotmail.com

Marina Sena Lopes da Silva Saccheto

ORCID: https://orcid.org/0000-0002-8433-941X Federal University of Minas Gerais, Brazil E-mail: marinaslopes@yahoo.com.br

Rafael Silva Lima

ORCID: https://orcid.org/0000-0001-7216-6147 Federal University of Minas Gerais, Brazil E-mail: rafaelslima7@yahoo.com.br

Simone Angélica de Faria Amormino ORCID: https://orcid.org/0000-0001-6247-8825 Centro Universitário de Belo Horizonte, Brazil E-mail: simoneamormino@hotmail.com

\begin{abstract}
Oral hygiene deficiency is common in intensive care unit (ICU) patients, which potentiates biofilm colonization by microorganisms that lead to respiratory infections. The literature has been reporting the association between oral health and systemic diseases, especially the development of ventilator-associated pneumonia (VAP). The objective of this study is to shed light on the performance and importance of the dental surgeon in an ICU. This is an integrative review performed in the PubMed database. It was adopted as the inclusion criteria papers in Portuguese or English, available as full-text papers, published from 2016 to 2021, and that answer the guiding question: what is the professional performance and importance of a dental surgeon in an ICU? After reading the title and abstract, 8 articles that reported the relationship between oral health and systemic disease were selected, especially regarding the development of VAP. Through this review we conclude how much it is indispensable the presence of a dental surgeon as part of an ICU multidisciplinary team, ensuring that the patient will be treated in an integral way and have their quality of life improved.
\end{abstract}

Keywords: Dental surgeon; Hospitalar odontology; Intensive care unit; Oral health.

\section{Resumo}

A deficiência de higiene oral é comum em pacientes tratados em unidade de terapia intensiva, possibilitando a colonização do biofilme por microorganismos que levam ao aparecimento das infecções respiratórias. A literatura tem relatado a relação entre saúde bucal e doenças sistêmicas, especialmente em relação ao desenvolvimento de pneumonia associada à ventilação mecânica (PAVM). O objetivo deste estudo é evidenciar a atuação e importância do cirurgião-dentista em uma unidade de terapia intensiva. Trata-se de uma revisão integrativa realizada na base de dados do PubMed. Adotou-se como critério de inclusão artigos em português ou inglês, disponíveis na íntegra, publicados no período de 2016 a 2021 e que responderam à questão norteadora: Qual a atuação e importância do cirurgião dentista em uma unidade de terapia intensiva? Após leitura do título e resumo, foram selecionados 8 artigos que relataram a relação entre saúde bucal e doença sistêmica, principalmente no que diz respeito ao desenvolvimento de pneumonia associada á ventilação mecânica. Concluímos através dessa revisão o quanto é indispensável a presença do cirurgião dentista sendo parte integrante da equipe multidisciplinar de uma unidade de terapia intensiva, garantindo que o paciente seja atendido de forma integral e melhorando sua qualidade de vida.

Palavras-chave: Cirurgião dentista; Odontologia hospitalar; Unidade de terapia intensiva; Saúde bucal.

\section{Resumen}

La deficiencia en la higiene bucal es común en pacientes tratados en una unidad de cuidados intensivos, lo que permite la colonización del biofilm por microorganismos que conducen a la aparición de infecciones respiratorias. La 
literatura ha informado de la relación entre la salud bucal y las enfermedades sistémicas, especialmente en relación con el desarrollo de neumonía asociada al ventilador (NAV). El objetivo de este estudio fue resaltar el papel y la importancia del odontólogo en una unidad de cuidados intensivos. Esta es una revisión integradora realizada en la base de datos PubMed. Adoptamos como criterios de inclusión los artículos en portugués o inglés, disponibles en su totalidad, publicados en el período de 2016 a 2021 y que respondieron a la pregunta orientadora: ¿Cuál es el papel y la importancia del cirujano dentista en una unidad de cuidados intensivos? Después de leer el título y el resumen, se seleccionaron 8 artículos que informaron la relación entre la salud bucal y la enfermedad sistémica, especialmente con respecto al desarrollo de neumonía asociada al ventilador. Concluimos a través de esta revisión lo fundamental que es la presencia del cirujano dentista, ser parte integral del equipo multidisciplinar de una unidad de cuidados intensivos, procurando que el paciente sea tratado de manera integral y mejorando su calidad de vida.

Palabras clave: Cirujano dentista; Odontología hospitalaria; Unidad de terapia intensiva; Salud bucal.

\section{Introduction}

The attention to oral hygiene is not a modern concern. The beginning of odontology's history, known as ars dentistica, is closely related to the history of medicine. The twentieth century was a period of important changes in odontology. It was in this period that the procedures became less harmful and turned to be more regenerative and focused on prevention (Morais \&, 2015).

In 2008, the Brazilian Federal deputy Neilton Mulim presented bill number 2.776-B/2008 that established the mandatory presence of dentists in the multidisciplinary team working in the intensive care unit (ICU) (Brazil, 2008). An ICU is defined as the hospital unit that cares for critically ill or high-risk patients who may have a potential improvement in their health condition but need medical care and support of a multidisciplinary team (Morais \& Silva, 2015).

The literature has demonstrated the influence of oral health conditions on the evolution of hospitalized patients. The evaluation of oral health and the need for oral treatment of hospitalized patients requires the intervention of a dental surgeon. This is justified due to the demand for control of bacterial biofilm and periodontal disease, elimination of caries, diagnosis of oral lesions due to systemic fungi and viral infections, and diagnosis of traumatic lesions and of other alterations that present an imminent risk or discomfort to the hospitalized patients (Ticianel \&, 2020).

Deficiency in oral hygiene is a common finding in ICU patients. It potentiates the colonization of the biofilm by microorganisms that could lead to respiratory infections (Miranda, 2016). The literature has been reporting the relationship between oral health and systemic diseases, especially the development of ventilator-associated pneumonia (VAP) (Oliveira \&, 2019). This kind of pneumonia is most often of aspirated origin, the secretion of the superior airways being the main source, followed by exogenous inoculation of contaminated material and gastrointestinal reflux. Approximately $33 \%$ of the patients die due to this infection (Agência Nacional de Vigilância Sanitária, 2017).

Odontology is of major importance for the prevention and control of inflammation in the oral cavity (AF \&, 2017). Although oral hygiene is an important measure in the context of ICU patients, it has been shown that this practice is still neglected (Ticianel, et al., 2020). The objective of this study is to shed light on the performance and importance of the dental surgeon in an ICU.

\section{Methodology}

This is an integrative literature review that aimed to synthesize the results obtained by scientific research on the topic described in the objective of this review, doing so systematically and widely. Its development has gone through six levels, including identification of the subject; determination of inclusion and exclusion criteria; definition and characterization of the information that will be retrieved from the studies; evaluation of the included studies; interpretation of the results; presentation of the review (Mendes \&, 2008).

Given the theme of the present review, the question that guided our search was: what is the performance and 
importance of a dental surgeon in an ICU? In the selection process, the Pubmed database was searched to find and retrieve relevant articles. It was employed as descriptors the following terms: "Intensive Care Units", "Dentists", "Oral Health", and "Hospital Dentistry". The search was conducted using the descriptor "Intensive Care Units" and adding "Dentists", “Oral Health" or "Hospital Dentistry". For the combinations among these descriptors the Boolean operator "AND" was employed.

It was included in the present review articles available at Pubmed, considering the period of the last 5 years (from 2016 to 2021) and in English or Portuguese. It was also included articles that could provide evidence to answer the guiding question, articles that approach the importance of the dental surgeon in the ICU multidisciplinary team, articles that related dental interventions to reduce the occurrence of VAP, and articles that reported on dental treatments for patients under mechanical ventilation. Reviews, articles that did not answer the guiding question we proposed, and articles that did not comply with the inclusion criteria were excluded. Studies that were not related to the theme of the present review and those that included non-VAP pneumonia patients were also excluded. All studies identified through our search strategy had their titles and abstracts screened.

We also included in this review publications from the National Agency of Sanitary Vigilance (Anvisa) from Brazil. This material was elected to present the historical and legal arguments to support the performance and importance of the dentist in an ICU.

\section{Results}

From our initial search, we retrieved 2943 studies in the PubMed database. After the application of the inclusion and exclusion criteria, screening of the title and abstract, 8 studies were eligible to take part in the present narrative review. The results of our search are presented in Table 1.

Table 1: Publications found in the PubMed database in the period between 2016 and 2021.

\begin{tabular}{|c|c|c|c|c|}
\hline Keyword & $\begin{array}{l}\text { Number of } \\
\text { publications }\end{array}$ & $\begin{array}{c}\text { Scanned } \\
\text { publications }\end{array}$ & $\begin{array}{l}\text { Selected publications } \\
\text { after reading the title }\end{array}$ & $\begin{array}{l}\text { Selected publications after } \\
\text { reading the abstract }\end{array}$ \\
\hline "Intensive Care Units" & 38 & 16 & 4 & 3 \\
\hline \multicolumn{5}{|l|}{ AND "Dentists" } \\
\hline "Intensive Care Units" & 1592 & 132 & 9 & 4 \\
\hline \multicolumn{5}{|l|}{ AND “Oral Health” } \\
\hline "Intensive Care Units" & 1313 & 101 & 3 & 1 \\
\hline \multicolumn{5}{|l|}{ AND "Hospital Dentistry" } \\
\hline Total & 2943 & 249 & 16 & 8 \\
\hline
\end{tabular}

Source: Authors (2021).

From the 8 articles selected through our search, 3 were from Brazil, 2 from the USA, 1 from Jordan, 1 from South Korea, and 1 from Canada. Considering the types of studies selected, we found qualitative and quantitative studies. The most prevalent theme was the relationship between nurses and the oral health of ICU patients. Our search also identified themes such as the relationship between oral hygiene and VAP, the inclusion of the dental surgeon in the ICU team to prevent respiratory infections, and the relationship between mechanical ventilation and VAP. 
Table 2: Features of the articles included in the present narrative review.

\begin{tabular}{|c|c|c|c|c|}
\hline Title & $\begin{array}{l}\text { Country/ } \\
\text { Year }\end{array}$ & $\begin{array}{c}\text { Experimental } \\
\text { design }\end{array}$ & Concluding Remarks & Reference \\
\hline $\begin{array}{l}\text { Is it necessary to have a } \\
\text { dentist within an intensive } \\
\text { care unit team? Report of a } \\
\text { randomized clinical trial }\end{array}$ & $\begin{array}{c}\text { Brazil/ } \\
2018\end{array}$ & Quantitative & $\begin{array}{l}\text { From an interprofessional standpoint, the } \\
\text { results corroborate the idea of including } \\
\text { dentists in the ICU workforce to improve } \\
\text { the oral health of critical patients and } \\
\text { prevent airway infections. It was also } \\
\text { shown that there was an improvement in } \\
\text { oral hygiene using only chlorhexidine. }\end{array}$ & $\begin{array}{c}\text { Belissimo- } \\
\text { Rodrigues et al. } \\
\text { (2018) }\end{array}$ \\
\hline $\begin{array}{l}\text { Nurses' perception and } \\
\text { attitudes towards oral care } \\
\text { practices for mechanically } \\
\text { ventilated patients }\end{array}$ & Jordan/2018 & $\begin{array}{c}\text { Cross-sectional } \\
\text { Descriptive and } \\
\text { Quantitative }\end{array}$ & $\begin{array}{l}\text { The inaccurate perception and attitudes of } \\
\text { ICU nurses towards oral care for patients } \\
\text { under mechanical ventilation require urgent } \\
\text { action from the clinical managers. Intra- } \\
\text { hospital training about the protocols } \\
\text { regarding oral hygiene can improve the } \\
\text { perception and attitudes of ICU nurses. }\end{array}$ & $\begin{array}{c}\text { Alja'Afreh, Mosleh, } \\
\text { Habashneh (2018) }\end{array}$ \\
\hline $\begin{array}{l}\text { A Nurse-Driven Oral Care } \\
\text { Protocol to Reduce Hospital- } \\
\text { Acquired Pneumonia }\end{array}$ & USA/2019 & Quantitative & $\begin{array}{l}\text { Nurses improve pneumonia outcomes if } \\
\text { they successfully provide oral care to all } \\
\text { hospitalized patients. This reduced costs, } \\
\text { hospitalization period, and mortality. }\end{array}$ & Warren et al. (2019) \\
\hline $\begin{array}{l}\text { Oral hygiene in intensive care } \\
\text { unit patients with } \\
\text { photodynamic therapy: study } \\
\text { protocol for randomized } \\
\text { controlled trial }\end{array}$ & Brazil/2017 & Qualitative & $\begin{array}{l}\text { In the ICU, nosocomial infections are } \\
\text { highly prevalent conditions and have been } \\
\text { related to high mortality. It has been } \\
\text { suggested that insufficient oral hygiene and } \\
\text { VAP are associated. }\end{array}$ & Collina et al. (2017) \\
\hline $\begin{array}{l}\text { Development of a } \\
\text { competency for professional } \\
\text { oral hygiene care of } \\
\text { endotrachally-intubated } \\
\text { patients in the intensive care } \\
\text { unit: development and } \\
\text { validity evidence }\end{array}$ & $\begin{array}{c}\text { South } \\
\text { Korea/2021 }\end{array}$ & Qualitative & $\begin{array}{l}\text { The professionals involved in oral hygiene } \\
\text { in the ICU need to establish a cooperative } \\
\text { system to provide quality oral care to the } \\
\text { patients. }\end{array}$ & Choi et al. (2021) \\
\hline $\begin{array}{l}\text { Factors influencing oral care } \\
\text { in intubated intensive care } \\
\text { patients }\end{array}$ & Canada/2019 & $\begin{array}{c}\text { Descriptive and } \\
\text { Quantitative }\end{array}$ & $\begin{array}{l}\text { Oral hygiene is an example of the } \\
\text { importance of nurses in the promotion of } \\
\text { quality oral care to fight nosocomial } \\
\text { infections in the ICU environment. }\end{array}$ & $\begin{array}{c}\text { Tanguay et al. } \\
\text { (2019) }\end{array}$ \\
\hline $\begin{array}{l}\text { Oral Care as a Prevention for } \\
\text { Nonventilator Hospital- } \\
\text { Acquired Pneumonia: A } \\
\text { Four-Unit Cluster } \\
\text { Randomized Study }\end{array}$ & USA/2021 & Qualitative & $\begin{array}{l}\text { Critically ill patients are in critical danger } \\
\text { for Nonventilator Hospital-Acquired } \\
\text { Pneumonia (NV-HAP) and the associated } \\
\text { morbidity and mortality of this condition. } \\
\text { Prevention of NV-HAP through oral care is } \\
\text { of high importance. }\end{array}$ & $\begin{array}{l}\text { Giuliano et al. } \\
\text { (2021) }\end{array}$ \\
\hline $\begin{array}{l}\text { Impact of oral hygiene } \\
\text { involving toothbrushing } \\
\text { versus chlorhexidine in the } \\
\text { prevention of ventilator- } \\
\text { associated pneumonia: a } \\
\text { randomized study }\end{array}$ & Brazil/2017 & Qualitative & $\begin{array}{l}\text { The results showed that, among the patients } \\
\text { subjected to toothbrushing, there was a } \\
\text { significant reduction in the duration of } \\
\text { mechanical ventilation, as well as a } \\
\text { tendency to reduce the incidence of VAP } \\
\text { and the time of permanence in the ICU. }\end{array}$ & Vidal et al. (2017) \\
\hline
\end{tabular}




\section{Discussion}

The performance of the dental surgeon in diagnosis, treatment, and control of oral complications in the ICU is increasingly important (Agência Nacional de Vigilância Sanitária, 2017). ICU patients often present compromised immunity and are exposed to multiple pathogens (Choi \&, 2021). During the ICU stay period, oral biofilm and tongue saburra increase simultaneously (Collina \&, 2017). The dental practice needs to be oriented towards the control of oral biofilm through the mechanical action of toothbrushing, saburra elimination, in addition to guidelines to the nursing team regarding the best practices and preventive actions for patient health and comfort (Souza \&, 2020). In this context, among the functions of the dental surgeon it is included diagnosis and treatment of oral conditions that may maintain or worsen severe systemic disorders, evaluation of the oral health on the onset, diagnosis and treatment of odontogenic infections, removal of plaque-retention factors that present infectious potential - residual roots, lesions of caries, orthodontic appliances, total or partial prostheses -, application of laser-therapy in lesions of soft and hard tissues of the oral cavity, and molding and confection of an interocclusal plate for the protection of teeth and mucosa (Ticianel, et al., 2020).

Evidence suggests that procedures involving oral health must be performed within $72 \mathrm{~h}$ from admission. These procedures include mechanical control of biofilm, mucosal hydration, diagnostic assessment, intensive mouth disinfection removing acute infection foci and risk factors from the patient (Agência Nacional de Vigilância Sanitária, 2017).

Mechanical ventilation is a supporting method for treating patients with acute or chronic respiratory insufficiency. Mechanical ventilation maintains gas exchange in the lungs, alleviates the stress of the respiratory muscles, and reverses or prevents fatigue of the respiratory muscles (Silva \&, 2020). Due to the orotracheal intubation for mechanical ventilation, the mouth stays open during the ICU stay, which increases the formation of bacterial plaque and decreases salivation (xerostomia). In the ICU, infectious diseases are highly prevalent and are responsible for the high mortality of hospitalized patients and in the context of mechanical ventilation, the lung is the most affected organ (Collina, et al., 2017).

Oral colonization is considered one of the most critical risk factors for VAP. VAP refers to pneumonia that occurs $48 \mathrm{~h}$ or more after the insertion of an endotracheal tube for mechanical ventilation (Tanguay \&, 2020). Mechanical ventilation increases VAP risk 1.3-fold for each day, thus increasing treatment cost (Alja'Afreh \&, 2018).

Training of the multi-professional team is fundamental and has a direct impact on the incidence of VAP in the ICU. Among the preventive measures used for reducing the incidence of VAP, it can be mentioned the maintenance of the patient in elevated decubitus to minimize microaspiration, effective aspiration, adjustment of the level of sedation, spontaneous breathing testing, protection of the gastric mucosa to avoid the formation of ulcers and proliferation of microorganisms, anticoagulation to avoid thrombi formation, cuff pressure monitoring, and performing oral hygiene using chlorhexidine $0,12 \%$. The dental surgeon is highly important in training the nursing staff regarding the oral hygiene of patients under mechanical ventilation, thus contributing to the prevention of VAP (Souza \&, 2020). In addition to the aspiration of pathogens colonizing the oropharynx, inhalation of aerosols containing bacteria, transmission through blood, and translocation of gut bacteria, are sources of microorganisms for VAP. The oral cavity, specifically, is subject to continuous colonization, and bacterial plaque serves as a permanent reservoir of microorganisms (Souza \&, 2013).

Pneumonia occurs when the microorganisms move to the lungs via entrance sites, such as the oral cavity, and elicit an inflammatory response. Within $48 \mathrm{~h}$ of hospitalization, it may occur alterations in the oral microbiota, especially with the predominance of pathogens associated with the onset of pneumonia. Respiratory pathogens, such as Staphylococcus aureus, Klebsiella pneumonia, Enterobacter cloacae, and Pseudomonas aerugi, which colonize the dental plaque can be inhaled and introduced to the lungs (Giuliano \&, 2021).

It is estimated that $9 \%$ to $40 \%$ of infections acquired in the ICU are cases of pneumonia related to mechanical 
ventilation and are associated with increased ICU stay length, morbidity, and mortality, which affects hospital costs. The same study claims that patients who received toothbrushing had significantly decreased mechanical ventilation duration, thus decreasing the incidence of VAP and the length of ICU stay (Vidal \&, 2017). Oral hygiene is an efficient and low-cost method to reduce the colonization of respiratory pathogens (Tanguay, et al., 2020).

Oral hygiene is fundamental to reduce the risk of pneumonia and for adequate oral care, an evaluation of the patient is essential. Thus, the comprehension of the oral condition of a patient is of first importance to know which procedures this patient needs (Choi, et al., 2021). In a European study, 88.1\% of ICU nurses reported that providing oral care to patients was their main priority (Rello \&, 2007). In a Malaysian study, 84.7\% of ICU nurses reported that they need better training for providing good oral health to patients (Soh \&, 2011). Although nurses recognize oral care as of high priority, the studies revealed that oral hygiene was considered a difficult and unpleasant procedure, for which nurses have insufficient knowledge (Alja'Afreh, et al., 2018).

In Brazil, a study conducted in a private hospital in Porto Alegre city has shown that $72.8 \%$ of nursing technicians recognize the importance of oral hygiene in critical patients. Although this study reports that nurses seek updates on this theme, the professionals claim they do not receive specific guidelines concerning the oral health of hospitalized patients (Orlandini \&, 2012). According to a resolution from Anvisa, ICU patients must receive dental assistance (Agência Nacional de Vigilância Sanitária, 2010). However, due to the delay in approving a federal law, the insertion of dental professionals in the hospital environment is still limited. Most Brazilian states still do not have a specific law that mandates the presence of the dental surgeon in the ICU, which results in the absence of a specialized professional who is capable of preventing and treating the oral affections (Silva \&, 2020).

Studies carried in the USA and Europe concluded that evidence-based oral hygiene practices are able to reduce the incidence of VAP in ICU patients. The studies identified adequate tools to provide efficient oral hygiene, including chemicals. Nevertheless, evidence-based and standardized guidelines for nursing practices concerning oral health for the prevention of VAP are seldom employed (Yoo \&, 2021). It was found that improving the knowledge of nurses could provide confidence to make better decisions regarding oral health, thus improving patient care and decreasing hospital stay duration (Alja'Afreh, et al., 2018).

According to Belissimo-Rodrigues et al. (2018), patients attended by dentists presented higher oral hygiene index scores compared to those attended only by the nursery team during their ICU stay. Even though nurses recognize and understand the value of oral hygiene, there is still a gap between knowledge and practice (Warren \&, 2019). Therefore, intrahospital training regarding the daily procedures of oral hygiene may improve the perception of nurses (Alja'Afreh, et al., 2018).

Dentists may be able to provide education regarding the oral hygiene of ICU patients through a process involving the development of abilities, providing adequate training, and structured guiding information. ICU patients are not able to express or control their oral status, it is the responsibility of the dental surgeon to register the state of their oral health (Choi, et al., 2021).

\section{Conclusion}

As exposed in the present review, the studies corroborate the importance of the dental surgeon in an ICU, where oral hygiene and the clinical outcome of the hospitalized patients, especially regarding the occurrence of VAP, are closely related. Therefore, the importance of the dentist in the multidisciplinary team of the ICU is evident, ensuring that the patient receives integral care and, thus, improving their quality of life. An important aspect that needs to be addressed by future research is the 
Research, Society and Development, v. 10, n. 16, e10101622955, 2021

(CC BY 4.0) | ISSN 2525-3409 | DOI: http://dx.doi.org/10.33448/rsd-v10i16.22955

contribution of this professional in preventing pressure lesions in the face that could impair recovery and may lead to the development of severe infections, sepsis, and mortality. Importantly, it is necessary further studies that reaffirm the importance of the dental surgeon in the curing process and, consequently, the reduction of ICU stay length.

\section{References}

AF, M. (2017). The Dental Surgeons in the Hospital and their Professional Areas in Brazil: Hospitalization Units, Surgical Centers and Intensive Care Units. Journal of Community Medicine \& Health Education, 7(1). doi: 10.4172/2161-0711.1000505

Agência Nacional de Vigilância Sanitária. (2010). Resolução $\quad \mathrm{n}^{\circ} \quad 7, \quad 24 \quad$ de $\quad$ fevereiro $\quad$ de 2010 . https://bvsms.saude.gov.br/bvs/saudelegis/anvisa/2010/res0007_24_02_2010.html

Agência Nacional de Vigilância Sanitária. (2017). Critérios diagnósticos de infecção relacionada à assistência à saúde. Brasilia, Brazil: Agência Nacional de Vigilância Sanitária.

Alja'afreh, M. A., Mosleh, S. M., \& Habashneh, S. S. (2018). Nurses' perception and attitudes towards oral care practices for mechanically ventilated patients. Saudi Medical Journal, 39(4), 379-385. doi: 10.15537/smj.2018.4.21749

Bellissimo-Rodrigues, W. T., Menegueti, M. G., Gaspar, G. G., de Souza, H. C. C., Auxiliadora-Martins, M., Basile-Filho, A., Martinez, R., \& BellissimoRodrigues, F. (2018). Is it necessary to have a dentist within an intensive care unit team? Report of a randomised clinical trial. International Dental Journal, 68(6), 420-427. doi: 10.1111/idj.12397

Brazil. (2018). Câmara dos PL-2.776-B2008. https://www.camara.leg.br/proposicoesWeb/prop_mostrarintegra;jsessionid=ADE697BEAF7144851AE6AA567350FA0F.node2?codteor=1077018\&filename $=$ Avulso+PL+2776/2008

Choi, E. S., Noh, H. J., Chung, W. G., \& Mun, S. J. (2021). Development of a competency for professional oral hygiene care of endotracheally-intubated patients in the intensive care unit: development and validity evidence. BMC Health Services Research, 21(1). doi: 10.1186/s12913-021-06755-Z

Collina, G. A., Tempestini-Horliana, A. C. R., da Silva, D. D. F. T., Longo, P. L., Makabe, M. L. F., \& Pavani, C. (2017). Oral hygiene in intensive care unit patients with photodynamic therapy: study protocol for randomised controlled trial. Trials, 18(1). doi: 10.1186/s13063-017-2133-y

Giuliano, K. K., Penoyer, D., Middleton, A., \& Baker, D. (2021). Original Research: Oral Care as Prevention for Nonventilator Hospital-Acquired Pneumonia. AJN, American Journal of Nursing, 121(6), 24-33. doi: 10.1097/01.naj.0000753468.99321.93

Mendes, K. D. S., Silveira, R. C. D. C. P., \& Galvão, C. M. (2008). Revisão integrativa: método de pesquisa para a incorporação de evidências na saúde e na enfermagem. Texto \& Contexto - Enfermagem, 17(4), 758-764. doi: 10.1590/s0104-07072008000400018

Miranda, A. F. (2016). Oral Health and Care at Intensive Care Units. Journal of Nursing \& Care, 5(6). doi: 10.4172/2167-1168.1000375

Morais, T. M., Silva, A. (2015). Fundamentos da odontologia em ambiente hospitalar/uti. Rio de Janeiro, Brazil: Elsevier.

Oliveira, G. M. S., Lima, C. B., Santos, R. N. R. R., \& Leite, V. K. P. (2019). Analysis of Protocols of Bucal Hygienization in Patients in the Intensive Therapy Unit (ICU). International Journal of Oral and Dental Health, 5(1). doi: 10.23937/2469-5734/1510079

Orlandini, G. M., \& Lazzari, C. M. (2012). Conhecimento da equipe de enfermagem sobre higiene oral em pacientes criticamente enfermos. Revista Gaúcha de Enfermagem, 33(3), 34-41. doi: 10.1590/s1983-14472012000300005

Rello, J., Koulenti, D., Blot, S., Sierra, R., Diaz, E., de Waele, J. J., Macor, A., Agbaht, K., \& Rodriguez, A. (2007). Oral care practices in intensive care units: a survey of 59 European ICUs. Intensive Care Medicine, 33(6), 1066-1070. doi: 10.1007/s00134-007-0605-3

Silva, D. H. F., Camargos, J. H. D., Rodrigues, J. G., Nogueira, L. S., Azevedo, D. A. D., Carvalho, M. D. G., \& Pinheiro, M. D. B. (2020). Impact of oral hygiene in patients undergoing mechanical ventilation in the COVID-19 pandemic. Revista Da Associação Médica Brasileira, 66(suppl 2), 96-101. doi: $10.1590 / 1806-9282.66 . s 2.96$

Silva, G. E. M., Thomsen, L. P. D. R., Lacerda, J. C. T., Botelho, S. H. B., Reis, J. A. C., Ferreira, R. D. D. A., \& Resende, R. G. (2020). Odontologia hospitalar no Brasil: onde estamos? Uma análise do cenário dos últimos anos. Revista Da Faculdade de Odontologia de Porto Alegre, 61(1), 94-100. doi: $10.22456 / 2177-0018.99716$

Soh, K. L., Soh, K. G., Japar, S., Raman, R. A., \& Davidson, P. M. (2011). A cross-sectional study on nurses' oral care practice for mechanically ventilated patients in Malaysia. Journal of Clinical Nursing, 20(5-6), 733-742. doi: 10.1111/j.1365-2702.2010.03579.x

Souza, A. F. D., Guimarães, A. C., \& Ferreira, E. F. E. (2013). Evaluation of the implementation of new protocol of oral hygiene in an intensive care center for prevention of pneumonia associated with mechanical ventilation. Reme: Revista Mineira de Enfermagem, 17(1). doi: 10.5935/1415-2762.20130015

Souza, L. C. D., Lopes, F. F. (2020). Odontologia na Rotina Assistencial em UTI. Curitiba, Brazil: Appris.

Tanguay, A., LeMay, S., Reeves, I., Gosselin, M., \& St-Cyr-Tribble, D. (2019). Factors influencing oral care in intubated intensive care patients. Nursing in Critical Care, 25(1), 53-60. doi: 10.1111/nicc.12456

Ticianel, A. K.; Matos, B. A. B; Vieira, E. M. M.; Rondon, F. R. C. (2020). Manual de odontologia hospitalar. Cuiabá, Brazil: Conselho Regional de Odontologia de Mato Grosso. 
Research, Society and Development, v. 10, n. 16, e10101622955, 2021

(CC BY 4.0) | ISSN 2525-3409 | DOI: http://dx.doi.org/10.33448/rsd-v10i16.22955

Vidal, C. F. L., Vidal, A. K. D. L., Monteiro, J. G. D. M., Cavalcanti, A., Henriques, A. P. D. C., Oliveira, M., Godoy, M., Coutinho, M., Sobral, P. D., Vilela, C. N., Gomes, B., Leandro, M. A., Montarroyos, U., Ximenes, R. D. A., \& Lacerda, H. R. (2017). Impact of oral hygiene involving toothbrushing versus chlorhexidine in the prevention of ventilator-associated pneumonia: a randomized study. BMC Infectious Diseases, 17(1). doi: 10.1186/s12879-017-2188-0

Warren, C., Medei, M. K., Wood, B., \& Schutte, D. (2019). A Nurse-Driven Oral Care Protocol to Reduce Hospital-Acquired Pneumonia. AJN, American Journal of Nursing, 119(2), 44-51. doi: 10.1097/01.naj.0000553204.21342.01

Yoo, J. Y., Oh, E. G., Hur, H. K., \& Choi, M. N. (2012). Level of Knowledge on Evidence-based Infection Control and Influencing Factors on Performance among Nurses in Intensive Care Unit. Korean Journal of Adult Nursing, 24(3), 232-243. doi: 10.7475/kjan.2012.24.3.232 